\title{
Infectious Diseases and Mass Gatherings
}

\author{
Van-Thuan Hoang ${ }^{1,2} \cdot$ Philippe Gautret ${ }^{1}$
}

Published online: 28 August 2018

(C) Springer Science+Business Media, LLC, part of Springer Nature 2018

\begin{abstract}
Purpose of Review Mass gatherings (MGs) are characterized by a high concentration of people at a specific time and location. Infectious diseases are of particular concern at MGs. The aim of this review was to summarize findings in the field of infectious diseases with a variety of pathogens associated with international MGs in the last 5 years.

Recent Findings In the context of Hajj, one of the largest religious MGs at Mecca, Saudi Arabia, respiratory tract infections are the leading cause of infectious diseases in pilgrims with a prevalence of 50-93\%. The most commonly acquired respiratory viruses were human rhinovirus, followed by human coronaviruses and influenza A virus, in decreasing order. Haemophilus influenzae, Staphylococcus aureus, and Streptococcus pneumoniae were the predominant bacteria. The prevalence of Hajjrelated diarrhea ranged from 1.1 to $23.3 \%$ and etiologies included Salmonella spp., and Escherichia coli, with evidence of acquisition of antimicrobial-resistant bacteria. In other MGs such as Muslim, Christian, and Hindu religious events, sports events, and large-scale open-air festivals, outbreaks have been reported less frequently. The most common outbreaks at these events involved diseases preventable by vaccination, notably measles and influenza. Gastrointestinal infections caused by a variety of pathogens were also recorded.

Summary Because social distancing and contact avoidance are difficult measures to implement in the context of many MGs, individual preventive measures including vaccination, use of face mask, disposable handkerchief and hand hygiene may be recommended. Nevertheless, the effectiveness of these measures has been poorly investigated in the context of MGs.
\end{abstract}

Keywords Infectious diseases $\cdot$ Outbreaks $\cdot$ Mass gatherings $\cdot$ Hajj $\cdot$ Sport $\cdot$ Festival

\section{Introduction}

The WHO defines mass gatherings (MGs) as a "concentration of people at a specific location for a specific purpose over a set period of time which has the potential to strain the planning and response resources of the country or community" [1].

This article is part of the Topical Collection on Tropical, Travel, and Emerging Infections

Philippe Gautret

philippe.gautret@club-internet.fr

1 IRD, AP-HM, SSA, VITROME, Institut Hospitalo-Universitaire Méditerranée Infection, Aix Marseille University, 19-21 Boulevard Jean Moulin, 13385 Marseille Cedex 05, France

2 Thai Binh University of Medicine and Pharmacy, Thai Binh, Vietnam
MGs can be either planned or spontaneous and recurrent or sporadic [1]. Planned MGs may include sporting, social, cultural, religious, and political events. Examples include music festivals, the Olympic Games, and the Hajj [2].

Spontaneous MGs, given their nature, are more difficult to plan for and may include events, such as funerals of religious and political figures [1,2]. MGs may also include the gatherings of displaced populations due to natural disasters, conflicts, and wars [1]. Diverse health risks are associated with MGs, including transmission of infectious disease, non-communicable disease, trauma and injuries (occupational or otherwise), environmental effects (such as, heatrelated illnesses, dehydration, hypothermia), illnesses related to the use of drugs and alcohol, and deliberate acts, such as terrorist attacks [1]. Infectious diseases are of particular concern at MGs [3]. In this review, we summarize recent findings in the field of infectious diseases associated with international MGs. 


\section{Results and Discussion}

\section{The Hajj (Table 1)}

The Hajj, an annual Muslim pilgrimage to Mecca, Saudi Arabia, is one of the largest religious MGs in the world with about two million pilgrims from 185 countries [4]. As part of the Hajj rituals, pilgrims visit various sacred places around the city of Mecca. Most of them also travel to the city of Medina to visit the second holiest site of Islam, the Prophet's mosque containing the tomb of the Prophet Muhammad. The presence of a large number of pilgrims from different countries of the world and overcrowded condition considerably increases the risk of occurrence of infectious diseases, particularly respiratory and gastrointestinal diseases [5]. Furthermore, a vast majority of pilgrims are elderly people with a high prevalence of chronic diseases. In the past, Hajj-related cholera has been a public health problem and the main cause of morbidity and mortality among pilgrims, leading to major epidemics and international spread. Due to improved sanitary conditions in Saudi Arabia in general and at religious sites, large-scale cholera outbreaks have not been recorded during the last decades [6,7]. Similarly,

Table 1 Hajj and large-scale open-air festivals - key points

\begin{tabular}{|c|}
\hline Hajj-key points \\
\hline - Event: annual Muslim pilgrimage \\
\hline - Place: Mecca, Saudia Arabia \\
\hline $\begin{array}{l}\text { - Population size: } 2 \text { million from } 185 \text { countries (high proportion of } \\
\text { elderly pilgrims with co-morbidities) }\end{array}$ \\
\hline $\begin{array}{l}\text { - Prevalence of respiratory symptoms in overall population of pilgrims: } \\
50-93 \%\end{array}$ \\
\hline $\begin{array}{l}\text { - Pneumonia among the leading cause of admission in Saudi hospitals } \\
\text { during the Hajj }\end{array}$ \\
\hline $\begin{array}{l}\text { - Acquisition of respiratory pathogens: } 13.5-34.1 \% \text { rhinovirus, } \\
\text { 12.4-14.6\% non-MERS coronavirus, } 1.9-7.8 \% \text { influenza A virus, } \\
\text { 7.1-36.6\% Streptococcus pneumoniae, } 11.4 \% \text { Haemophilus } \\
\text { influenzae, } 7.5 \% \text { Staphylococcus aureus }\end{array}$ \\
\hline $\begin{array}{l}\text { - No case of MERS-CoV, Bordetella pertussis, Mycoplasma } \\
\text { pneumoniae, and Chlamydia pneumoniae observed in pilgrims in } \\
\text { recent years }\end{array}$ \\
\hline - Antibiotic consumption in overall population of pilgrims: $45-61.8 \%$ \\
\hline - Prevalence of diarrhea: $1.1-23.3 \%$ \\
\hline $\begin{array}{l}\text { - Hajj-associated diarrhea mostly due to bacteria including: Salmonella } \\
\text { spp. and Escherichia coli. }\end{array}$ \\
\hline - Evidence for acquisition of antimicrobial-resistant bacteria \\
\hline Large-scale open-air festivals-key points \\
\hline $\begin{array}{l}\text { - Events: music festivals and other cultural festivals in various places in } \\
\text { the world. }\end{array}$ \\
\hline $\begin{array}{l}\text { - Population size: variable but usually less than } 400,000 \text { participants } \\
\text { (mostly young participants) }\end{array}$ \\
\hline $\begin{array}{l}\text { - Outbreaks of respiratory tract infections and gastrointestinal } \\
\text { infections are regularly reported including notably measles and }\end{array}$ \\
\hline
\end{tabular}

invasive meningococcal disease has been a Hajj-related public health concern with its last outbreaks (serogroup W-135) in the 2000s. However, with the strengthening of prevention through mandatory vaccination, no case of meningococcal disease has been reported in Mecca since $2006[8,9]$.

While gastrointestinal diseases and diarrhea have changed towards a lower prevalence, respiratory tract infections (RTIs) now account for the vast majority of health problems during the Hajj $[4,5]$. The inevitable overcrowding conditions at the Grand Mosque in Mecca and the accommodation in tents in Mina with an average of 50 to 100 people per tent are likely responsible for the high rate of respiratory infections among Hajj pilgrims [5].

\section{Respiratory Infections at the Hajj}

Over the last 5 years, a significant number of publications from different countries based on both syndromic surveillance and PCR-based investigation of respiratory pathogen carriage were made available. Studies were conducted in out- and inpatients at health structures in Saudi Arabia or on return in pilgrim's country of origin and in cohorts of pilgrims regardless of symptoms [10-34] (Table 2).

RTIs are among the leading causes of admission to hospitals in Mina, Mecca, and Medina during the Hajj period (Table 2). Most cases are upper respiratory tract infections [10-16], but severe respiratory tract infections [17] and pneumonia are not uncommon among pilgrims $\left[18,19,20^{\bullet}\right]$. Respiratory diseases were the second cause of mortality in Indonesian pilgrims during the Hajj (following cardiovascular diseases) [35]. Among pathogens detected by PCR methods in ill pilgrims, the most common viruses were human rhinovirus (HRV), followed by human coronaviruses $(\mathrm{HCoV})$ and influenza A virus (IAV). Haemophilus influenzae, Staphylococcus aureus, and Streptococcus pneumoniae were the predominant bacteria isolated by culture [36, 37].

Cross-sectional and longitudinal cohort studies have recorded 53-93.4\% prevalence of RTI symptoms among Hajj pilgrims [21-23, 26•, 28, 32, 34•]. The rate of ILI varied from 1.9 to $78.2 \%$ [21, 22, 26•, 27, 28, 30-33]. Cohort surveys allow evaluating the acquisition rate of respiratory pathogens regardless of symptoms. The most commonly acquired viruses were human rhinovirus (HRV) (13.5-34.1\%), followed by human coronavirus E229 (HCoV-E229) (2.0-14.6\%) and influenza virus (IAV) (1.9-20.0\%) [21, 22, 27, 28, 30, 31 • 33]. The most commonly acquired bacteria were $S$. pneumoniae (7.1 to $36.6 \%$ ) and S. aureus (7.5 to $22.8 \%$ ) and $H$. influenzae (11.4\%) [25, 28, 29, 31・, 34•]. Bordetella pertussis, Mycoplasma pneumoniae, and Chlamydia pneumoniae have not been detected in pilgrims in recent studies [13, 28, 31•]. Middle East Respiratory Syndrome Coronavirus (MERS$\mathrm{CoV}$ ) that emerged in the Arabian Peninsula in 2012 is associated with severe acute respiratory infection with high 


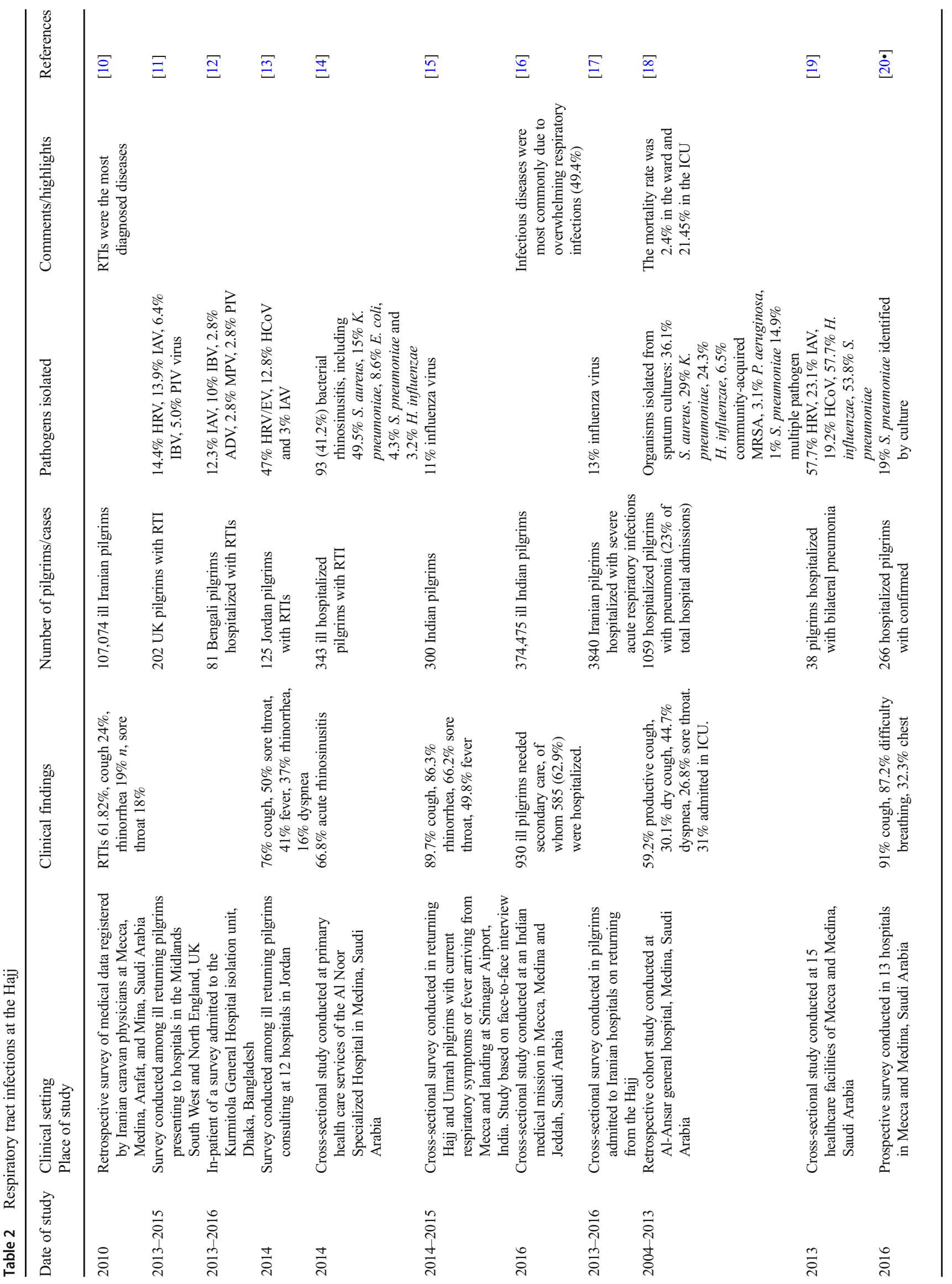




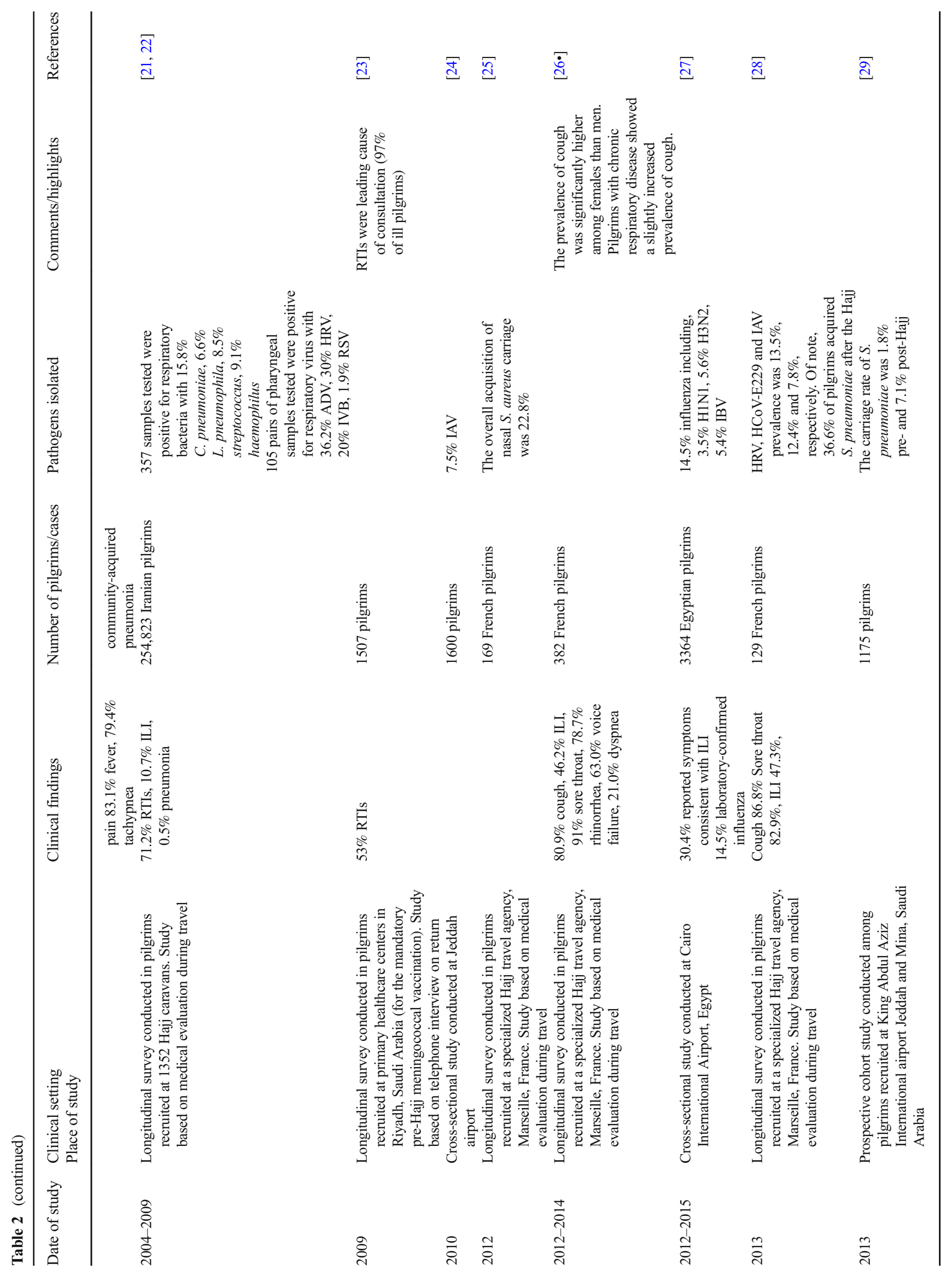




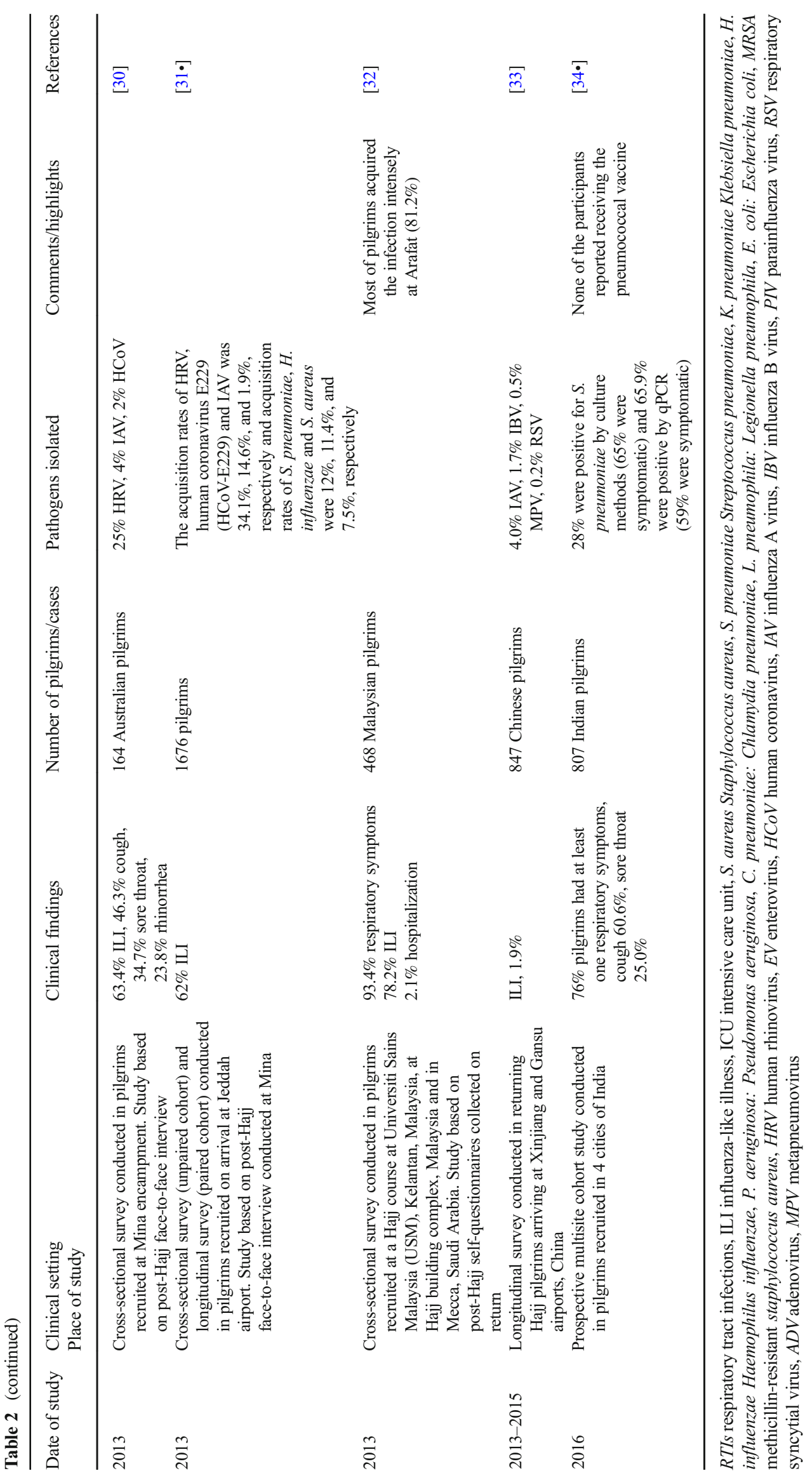


mortality rates. Numerous studies were conducted in returning pilgrims with the aim of detecting MERS-CoV infections and all resulted negative $[11-13,15,17,24,27,28,30,33$, 38-46].

Tuberculosis (TB) transmission is another concern at the Hajj, but there are no large-scale, specific studies to determine its prevalence among pilgrims [47]. A prospective crosssectional study was conducted in Mecca, during the Hajj period in September 2015. One thousand one hundred sixty-four pilgrims with cough were selected from five countries in Africa and South Asia that are endemic for TB and 1.4\% had active previously undiagnosed TB [48 0 . During the Hajj in 2015, 44 cases of TB among pilgrims and nonpilgrims were diagnosed in Mecca hospitals [48•].

\section{Gastrointestinal Diseases at the Hajj}

A review on diarrhea at the Hajj published in 2015 showed a prevalence of diarrhea ranging from 1.1 to $23.3 \%$ in 14 cohort studies including 262,999 pilgrims from various countries between 2002 and 2013 [49•]. Five percent of pilgrims from Riyadh developed diarrheal symptoms during the 2009 Hajj [23]. Twenty-one percent of Iranian female pilgrims suffered from gastroenteritis during the 2011 Hajj [50]. In 2013, 23.3\% pilgrims from Marseille, France, had diarrhea during the Hajj [51] while a $13.7 \%$ prevalence was recorded in 2016 [52]. In the latter study, Escherichia coli was the predominant pathogen isolated from pilgrims by PCR. Enteropathogenic E. coli, enteroaggregative $E$. coli, and Shiga-like toxin-producing $E$. coli were acquired by $29.9 \%, 10.2 \%$, and $6.5 \%$ pilgrims, respectively [52]. Among persons infected during the 2011-2013 Hajj and hospitalized in Saudi hospitals, the pathogens responsible for enteric infection were mostly bacteria, with a prevalence of Salmonella spp. of $11.4 \%$, while that of diarrhea associated E. coli ranged between 1.3 and $8.8 \%$ according to pathotypes [53]. Two cases of Tropheryma whipplei were recorded in a cohort of French pilgrims during the 2013 Hajj [51].

\section{Antibiotic Consumption During the Hajj}

The frequency of infectious diseases during the Hajj results in a significant demand for antibiotic use. The rate of antibiotic use among pilgrims varied according to their nationality and year with $61.8 \%$ in Malay pilgrims in 2013 [32], 53.8\% in French pilgrims in 2012 [25], 45-48.3\% in Indian pilgrims in 2016 [16, 34 ], and 58.5\% in Iranian pilgrims in 2012 [54]. A prospective study conducted among 218 pilgrims from Marseille, France, during the periods of Hajj in 2013-2014 showed that $54.8 \%$ of the population used antibiotics because of respiratory diseases and 5.4\% because of diarrhea [55]. Although the dispensing of antibiotics without a prescription has been banned in Saudi Arabia for more than 30 years [56], $27 \%$ of Australian pilgrims used antibiotics either delivered in
Saudi Arabia without prescription or purchased in Australia before traveling [57].

\section{Hajj and Antimicrobial-Resistant Bacteria}

The predominance of bacterial pathogens in Hajj-related gastrointestinal infections poses a major risk to public health through the potential emergence and transmission of antimicrobial-resistant bacteria [53]. Methicillin-resistant $S$. aureus had been isolated in $28 \%$ of pilgrims with acute sinusitis in 2014 [14] and $63 \%$ of pilgrims with communityacquired infections hospitalized during the Hajj in 2015 [58 $]$. One study addressed the carriage of resistant $S$. pneumoniae in a multinational cohort of pilgrims and showed that $23 \%$ of isolates were resistant to multiple antibiotics (resistant to three or more classes of antibiotics) [29]. Extended spectrum beta-lactamase Enterobacteriaceae are also common among hospitalized pilgrims. During the 2014-2015 Hajj, $47 \%$ of pilgrims attending hospitals for urinary tract infections showed blaCTX-M genes in E. coli isolates [59].

During the 2013 and 2014 Hajj seasons, studies were conducted using rectal samples obtained before and after the Hajj in cohorts of French pilgrims to assess the carriage of the blaCTX-M gene. Acquisition rates of 31.0-34.8\% were observed $[55,60]$. There was also a significant increase in the number of pilgrims harboring E. coli resistant to ceftriaxone and ticarcillin-clavulanic acid [60].

The prevalence of C3G-resistance was observed in $90.6 \%$ Acinetobacter baumannii isolates in a cohort of French pilgrims in 2014 [61] and in $76.2 \%$ of isolates obtained from hospitalized pilgrims suffering from community-acquired infections in 2015 [58 ]. Two French pilgrims carried $S$. enterica, resistant to ceftriaxone, gentamycin, and colistin after the 2013 Hajj [62]. Mrc-1 resistance gene screening from rectal swabs was conducted in French pilgrims in 2013-2014 and found an acquisition rate of $9.0 \%$ after Hajj [63].

Risk factors for the spread of antibiotic-resistant bacteria at the Hajj include international travel, misuse of antibiotics, and availability of over-the-counter antibiotics [64]. However, gastrointestinal diseases and diarrhea continue to occur in pilgrims, outbreaks of food poisoning are reported, and the acquisition of multi-resistant bacteria is emerging. The ongoing monitoring of these diseases is part of the public health response regarding the Hajj [49•, 55].

\section{Meningococcal Carriage at the Hajj}

Currently, meningococcal vaccination $(\mathrm{A}, \mathrm{C}, \mathrm{Y}, \mathrm{W}-135)$ is mandatory for all pilgrims, national and international, as well as local residents of holy cities and workers in contact with pilgrims; however, polysaccharide vaccine which does not prevent meningococcal carriage is still in use in many countries. Mandatory oral ciprofloxacin prophylaxis is provided 
upon arrival to all the pilgrims coming from the "meningitis belt" of sub-Saharan Africa [8, 9, 65, 66]. A cross-sectional study among pilgrims arrived at King Abdul Aziz International Airport, in Jeddah for the Hajj in 2012 showed antibody titers under the level of protection against serogroups A, C, W, and Y of only $0.1 \%, 0.4 \%, 17.4 \%$, and $9.4 \%$, respectively. Most of them $(98.2 \%)$ had received meningococcal vaccination in the three previous years [67]. In a prospective cohort study conducted in Turkish Hajj pilgrims during 2010, the carriage prevalence of Neisseria meningitides, assessed by culture method, was $13 \%$ before and $27.0 \%$ after the Hajj with the majority being serogroup W-135 [68]. In a prospective culture-based cohort study conducted among Iranian pilgrims in 2012, $1.4 \%$ acquired $N$. meningitides at the Hajj [54]. A prospective study conducted in 2014 among international pilgrims at King Abdul Aziz International Airport showed 3.0\% $N$. meningitides carriage by culture method upon arrival and $0.9 \%$ upon departure, with the majority of typable isolates being serogroup B [69]. Outbreaks of the disease including those due to serogroups not included in the required vaccines, such as serogroups B and X, are therefore possible at the Hajj. Despite the wide use of polysaccharide vaccine, it does not prevent the carriage of serogroup W-135 and subsequent transmission to unvaccinated individuals by returning pilgrims.

\section{Others Religious Meetings}

The Grand Magal of Touba, the largest Muslim pilgrimage in Senegal, has specific features. Besides its setting in a tropical environment, its population is characterized by a large range of age groups since most pilgrims travel with their family, including young children. A preliminary survey in 2015 has showed a high rate of febrile systemic illnesses and malaria (4.9\%), diarrheal diseases (4.5\%), and RTIs (5.2\%) among ill pilgrims consulting at health care structures during the pilgrimage. The overall hospitalization rate was $3.4 \%$ including gyneco-obstetric cases $(16.2 \%)$ and confirmed malaria $(14.5 \%)$ [70••].

The Kumbh Mela in India is the largest MG in the world with about 100 million visitors. It posed an exciting challenge to the provision of healthcare services. Increased population density, reduced sanitation, and exposure to environmental pollutants open the way for easy transmission of pathogens [71]. During Kumbh Mela in 2013, 412,703 patients consulted at hospitals. Respiratory infections accounted for $70 \%$ of illnesses and diarrheal diseases for 5\%. In total, 4429 (1.1\%) were hospitalized. Gastrointestinal disease risk, including cholera, is high because of potential contamination of water and food. In addition, vaccination against cholera is no longer considered adequate or even feasible in this context [72].

The Ashura MG at Karbala is an increasingly popular religious event in Iraq with about three to four million Muslims from within and outside Iraq. In 2010, a cross-sectional study conducted in three public hospitals at Karbala city showed that about $80 \%$ of the 18,415 consultations were at emergency rooms. Febrile illness was recorded seven times more frequently during this event compared to previous events, in relation to an eight-fold increase in the population in the area during the event [73].

Other notable events include the Moulay Abdellah Amghar Moussem, an 8-day annual gathering in Morocco, that documented an increase of gastrointestinal diseases from 11 to $14 \%$ between 2009 and 2010 [74]. During the 2010 anniversary of the death (Urs) of Baba Farid, an annual MG in Pakpattan, Pakistan, $58 \%$ of 5918 people seen at 15 healthcare facilities were affected by communicable diseases, including $26 \%$ gastrointestinal illnesses and 21\% RTIs [75]. Also in 2010, a cross-sectional study of 700,000 attendees to the 5-day Eid Al Adha holiday, Aqaba (one of the largest Muslim MGs in Jordan), identified $23 \%$ and $33 \%$ increases in emergency department attendance and hospital admissions, respectively; however, no food poisoning outbreaks were reported [76]. Unlike the syndromic surveillance data mentioned above that lacked reliable identification of the responsible pathogen, $S$. enterica serotype typhimurium was determined to cause 64 cases of gastrointestinal illness among 9000 participants in a Christian religious festival in Hamilton County, Ohio; the outbreak was associated with the consumption of pulled pork prepared in a private house and sold at the festival [77].

\section{Large-Scale Open-Air Festivals (Table 1)}

Although numerous gastrointestinal and respiratory outbreaks have been documented at large-scale open-air festivals, particularly music festivals, with thousands of participants, these events are probably neglected, in terms of public health attention, as well as surveillance and prevention of infectious disease strategies, compared to other categories of MGs [78]. Since this review was published, several outbreaks were reported in the context of festivals.

Between July 10 and 24, 2013, during the annual independence celebrations in Kiribati, the Kiribati Syndromic Surveillance System reported an increase in children presenting with severe diarrhea due to Rotavirus. In total, 1118 cases of gastroenteritis were reported and $6(0.5 \%)$ died among 103 $(9.2 \%)$ hospitalized. Most of them $(93.4 \%)$ were younger than 5 years of age [79].

An outbreak of measles with 44 cases identified at an international dog show occurred in November 2014 in Slovenia, where measles virus had not been circulating for many years. Twenty-three persons were infected there and 21 were presumable secondary and tertiary cases. Most cases (39) were adults. Five were unvaccinated children [80]. Also, a multistate measles outbreak that caught global attention occurred at the Disney theme parks in California, USA [81].

The 23rd World Scout Jamboree (WSJ) in Yamagushi, Japan, from July 28 to August 8, 2015, was a MG attended 
by more than 33,000 participants from 155 countries. The event is designed for scouts aged 14 to 17 years to live together, experience diverse cultures, and take part in recreational activities. In this event, six cases of invasive meningococcal disease related to the WSJ were reported, affecting 19.5 per 100,000 WSJ attendees, far exceeding the annual incidence rate in Japan in 2014 (0.03 per 100,000 population) [82•].

Finally, an outbreak of measles (52 cases) was reported at music and art festivals in England and Wales between June and October 2016. Almost half of the cases occurred in participants aged 15 to 19 years. Several people who contracted measles at a festival later attended another festival when they were contagious, resulting in multiple, interconnected outbreaks. Only one confirmed case was fully vaccinated. Forty-two were not vaccinated. Nine cases were not fully vaccinated, or their immunization status was unknown [83].

\section{Sport Events (Table 3)}

A review of outbreaks at large sport events including the Summer and Winter Olympics, FIFA world cup and the EURO football cup from 1984 through 2015 found little evidence for infectious outbreaks with the exception of 36 cases of influenza among participants to the Winter Olympiad in Salt Lake City in 2002 and a small outbreak of gastrointestinal disease affecting a single team during the pre-race sailing competition in Brazil in 2015, prior to the 2016 Olympics [84••].

An epidemic of measles occurred during the XXI Olympic Winter Games that were held in February 12-28, 2010, in Vancouver, Canada, with 82 cases [85]. Another epidemic of measles was noted during the 16th edition of the Italia Super Cup, international junior football tournament in Rimini, Italy, from June 2nd to 5th, 2011. Most ill individuals had not been vaccinated [86].

During the London 2012 Olympic and Paralympic Games, no major public health incidents occurred. Only a few outbreaks of gastrointestinal and respiratory infections were recorded during this period. No food-borne illness was directly linked to a Games venue, despite the tendency for those reporting them to label them as such [87]. During this event, 289 Olympic visitors were followed for sexually transmitted infections (STI), 47 new STI diagnoses were made including 15 non-specific genital infection, eight chlamydia, and eight

Table 3 Sport events - key points

- Events: Summer and Winter Olympics, FIFA world cup, EURO football cup

- Population size: variable 1-6 million attendees at largest events

- Outbreaks of respiratory tract infections have been reported, notably measles and influenza

- Gastrointestinal infections and diarrhea due to Salmonella spp. and norovirus have been recorded. genital warts (first episode) diagnoses. There were no new HIV or syphilis diagnoses [88].

During Euro 2012 European Football, according to national data from Ukraine, 1299 cases of acute gastroenteritis occurred in host cities, but daily notifications remained consistently below the epidemic threshold determined by Ukraine. Similarly, 109 measles cases were reported in the host cities during the tournament, only one of which occurred in a foreign visitor. This number represented about $10 \%$ of the new cases reported throughout Ukraine during the same period [89].

During the European Youth Olympic Festival in Utrecht, the Netherlands, in 2013, a prospective cohort study was conducted among 2272 participants from 49 countries. Forty-six cases of diseases were reported. Infection was the most commonly reported cause of illness (56.5\% overall) with $43.5 \%$ patients reporting gastrointestinal symptoms and $26.1 \%$ respiratory symptoms [90].

Among the 2788 athletes in the Sochi 2014 Olympic Winter Games, a total of 249 illnesses were reported, resulting in an incidence of 8.9 illnesses per 100 athletes (95\% CI 7.8 to 10.0). Most ill athletes suffered from respiratory symptoms (63.9\%), followed by gastrointestinal symptoms (11\%) with $58 \%$ caused by infections [91]. Only three cases of dengue fever were confirmed at the 2014 FIFA World Cup [92].

A recent multinational Salmonella outbreak was reported at an international youth ice hockey competition in Riga, Lativa in 2015 [93].

Among 11,274 athletes from 207 countries participating to the Rio de Janeiro 2016 Olympic Summer Games, 613 illnesses were reported, resulting in 5.4 illnesses per 100 athletes. Two hundred two individuals $(47 \%)$ presented with respiratory symptoms and $(n=131 ; 21 \%)$ gastrointestinal symptoms with $56 \%(n=346)$ due to infections [94]. Dengue case count was negligible and no case of Zika virus was detected $[95,96]$.

More recently, the Pyeong Ghang 2018 Winter Olympiad may have been hindered by a norovirus outbreak days before the event commenced. This outbreak affected mainly security staff for the games rather than athletes or visitors [97].

\section{Conclusion}

This review has some limitations. It was limited to articles written in English, which may have been a source of bias. There was a significant heterogeneity in the studies in relation to the populations studied, the clinical criteria for syndromic surveillance and the diagnostic methods applied.

Infectious diseases at MGs are dominated by respiratory tract and gastrointestinal infections. Meningitis outbreaks were also reported in some instances. Inter-human transmission of airborne diseases is favored by the temporal and spatial concentration of people. Because social distancing and contact 
avoidance are difficult measures to implement in the context of many MGs, individual preventive measures such as cough etiquette, the use of face mask and disposable handkerchiefs and hand hygiene may be recommended. Nevertheless, the effectiveness of these measures has been poorly investigated in the context of MGs. Most available data come from Hajj studies and results are contradictory [98].

Non-compliance with hygiene rules and inadequate sanitation are responsible for fecal-oral transmission of gastrointestinal infections. Public health measures aiming at provision of safe water and food supplies with rigorous quality control are likely the best way to limit the occurrence of gastrointestinal outbreaks at MGs. Planned organization by highly specialized teams of staff is a key element.

It should be noted that many MG-associated diseases are vaccine-preventable, including influenza, measles, mumps, meningococcal, and pneumococcal disease. Mandatory vaccination against meningitis has proven effective in the context of the Hajj. Measles and mumps and meningococcal vaccination status should certainly be verified and updated if needed in young people attending MGs. Influenza and pneumococcal vaccination should be recommended in at-risk individuals participating to MGs. This particularly applies to elderly people participating to religious MGs.

Finally, because of the evidence of circulation of resistant bacteria, at least in the Hajj context, rationalization of antibiotic consumption should be promoted.

Unfortunately, official recommendations for prevention at MGs are lacking, with the exception of the Hajj [99].

\section{Compliance with Ethical Standards}

Conflict of Interest Philippe Gautret and Van-Thuan Hoang declare that they have no conflict of interest.

Human and Animal Rights and Informed Consent This article does not contain any studies with human or animal subjects performed by any of the authors.

\section{References}

Papers of particular interest, published recently, have been highlighted as:

- Of importance

•. Of major importance

1. World Health Organization. Public health for mass gatherings: key considerations. Geneva: WHO; 2015.

2. World Health Organization. Communicable disease alert and response for mass gatherings: key considerations. Geneva: WHO; 2008.

3. Al-Tawfiq JA, Memish ZA. Mass gatherings and infectious diseases: prevention, detection, and control. Infect Dis Clin N Am. 2012;26(3):725-37. https://doi.org/10.1016/j.idc.2012.05.005.
4. Memish ZA, Zumla A, Alhakeem RF, Assiri A, Turkestani A, Al Harby KD, et al. Hajj: infectious disease surveillance and control. Lancet. 2014;383(9934):2073-82. https://doi.org/10.1016/S01406736(14)60381-0.

5. Abubakar I, Gautret P, Brunette GW, Blumberg L, Johnson D, Poumerol G, et al. Global perspectives for prevention of infectious diseases associated with mass gatherings. Lancet Infect Dis. 2012;12:66-74. https://doi.org/10.1016/S1473-3099(11)70246-8.

6. Ahmed QA, Arabi YM, Memish ZA. Health risks at the Hajj. Lancet. 2006;367(9515):1008-15. https://doi.org/10.1016/S01406736(06)68429-8.

7. Zumla A, McCloskey B, Endericks T, Azhar EI, Petersen E. The challenges of cholera at the 2017 Hajj pilgrimage. Lancet Infect Dis. 2017(9):895-7. https://doi.org/10.1016/S1473-3099(17) 30454-1.

8. Yezli S, Assiri AM, Alhakeem RF, Turkistani AM, Alotaibi B. Meningococcal disease during the Hajj and Umrah mass gatherings. Int J Infect Dis. 2016;47:60-4. https://doi.org/10.1016/j.ijid. 2016.04.007.

9. Yezli S. The threat of meningococcal disease during the Hajj and Umrah mass gatherings: a comprehensive review. Travel Med Infect Dis. 2018. https://doi.org/10.1016/j.tmaid.2018.05.003.

10. Marashi SA, Rusta H, Tabatabaei A. Chief complaints and diagnosis of patients visited by caravan physicians during hajj 2010. Iran Red Crescent Med J. 2014;16:e12858. https://doi.org/10.5812/ ircmj.12858.

11. Atabani SF, Wilson S, Overton-Lewis C, Workman J, Kidd IM, Petersen E, et al. Active screening and surveillance in the United Kingdom for Middle East respiratory syndrome coronavirus in returning travellers and pilgrims from the Middle East: a prospective descriptive study for the period 2013-2015. Int J Infect Dis. 2016;47:10-4. https://doi.org/10.1016/j.ijid.2016.04.016.

12. Muraduzzaman AKM, Khan MH, Parveen R, Sultana S, Alam AN, Akram A, et al. Event based surveillance of Middle East respiratory syndrome coronavirus (MERS-CoV) in Bangladesh among pilgrims and travelers from the Middle East: an update for the period 2013-2016. PLoS One. 2018;13(1):e0189914. https://doi.org/10. 1371/journal.pone.0189914.

13. Al-Abdallat MM, Rha B, Alqasrawi S, Payne DC, Iblan I, Binder AM, et al. Acute respiratory infections among returning Hajj pilgrims-Jordan, 2014. J Clin Virol. 2017;89:34-7. https://doi.org/10. 1016/j.jcv.2017.01.010.

14. Marglani OA, Alherabi AZ, Herzallah IR, Saati FA, Tantawy EA, Alandejani TA, et al. Acute rhinosinusitis during Hajj season 2014: prevalence of bacterial infection and patterns of antimicrobial susceptibility. Travel Med Infect Dis. 2016;14:583-7. https://doi.org/ 10.1016/j.tmaid.2016.11.004.

15. Koul PA, Mir H, Saha S, Chadha MS, Potdar V, Widdowson MA, et al. Influenza not MERS CoV among returning Hajj and Umrah pilgrims with respiratory illness, Kashmir, north India, 2014-15. Travel Med Infect Dis. 2017;15:45-7. https://doi.org/10.1016/j. tmaid.2016.12.002.

16. Khan ID, Khan SA, Asima B, Hussaini SB, Zakiuddin M, Faisal FA. Morbidity and mortality amongst Indian Hajj pilgrims: a 3-year experience of Indian Hajj medical mission in mass-gathering medicine. J Infect Public Health. 2018;11:165-70. https://doi.org/10. 1016/j.jiph.2017.06.004.

17. Yavarian J, Shafiei Jandaghi NZ, Naseri M, Hemmati P, Dadras M, Gouya MM, et al. Influenza virus but not MERS coronavirus circulation in Iran, 2013-2016: comparison between pilgrims and general population. Travel Med Infect Dis. 2018;2018(21):51-5. https://doi.org/10.1016/j.tmaid.2017.10.007.

18. Shirah BH, Zafar SH, Alferaidi OA, Sabir AMM. Mass gathering medicine (Hajj Pilgrimage in Saudi Arabia): the clinical pattern of pneumonia among pilgrims during Haij. J Infect Public Health. 2017;10(3):277-86. https://doi.org/10.1016/j.jiph.2016.04.016. 
19. Memish ZA, Almasri M, Turkestani A, Al-Shangiti AM, Yezli S. Etiology of severe community-acquired pneumonia during the 2013 Hajj-part of the MERS-CoV surveillance program. Int J Infect Dis. 2014(25):186-90. https://doi.org/10.1016/j.ijid.2014. 06.003.

20. AlBarrak A, Alotaibi B, Yassin Y, Mushi A, Maashi F, Seedahmed $\mathrm{Y}$, et al. Proportion of adult community-acquired pneumonia cases attributable to Streptococcus pneumoniae among Hajj pilgrims in 2016. Int J Infect Dis. 2018;69:68-74. https://doi.org/10.1016/j.ijid. 2018.02.008. This study shows the high prevalence of $\boldsymbol{S}$. pneumoniae among patients with community-acquired pneumonia hospitalized in Saudi hospitals during the Hajj.

21. Razavi SM, Mohazzab Torabi S, Salamati P. Treatment and prevention of acute respiratory infections among Iranian hajj pilgrims: a 5year follow up study and review of the literature. Med J Islam Repub Iran. 2014;28:31.

22. Razavi SM, Sabouri-Kashani A, Ziaee-Ardakani H, Tabatabaei A, Karbakhsh M, Sadeghipour H, et al. Trend of diseases among Iranian pilgrims during five consecutive years based on a Syndromic Surveillance System in Hajj. Med J Islam Repub Iran. 2013;27(4):179-85.

23. Al-Jasser FS, Kabbash IA, AlMazroa MA, Memish ZA. Patterns of diseases and preventive measures among domestic hajjis from Central, Saudi Arabia. Saudi Med J. 2012;33(8):879-86.

24. Ashshi A, Azhar E, Johargy A, Asghar A, Momenah A, Turkestani $\mathrm{A}$, et al. Demographic distribution and transmission potential of influenza A and 2009 pandemic influenza A H1N1 in pilgrims. J Infect Dev Ctries. 2014;8(9):1169-75. https://doi.org/10.3855/jidc. 4204.

25. Verhoeven PO, Gautret P, Haddar CH, Benkouiten S, Gagnaire J, Belhouchat K, et al. Molecular dynamics of Staphylococcus aureus nasal carriage in Hajj pilgrims. Clin Microbiol Infect. 2015;21(7): 650.e5-8. https://doi.org/10.1016/j.cmi.2015.03.020.

26. Gautret P, Benkouiten S, Griffiths K, Sridhar S. The inevitable Hajj cough: surveillance data in French pilgrims, 2012-2014. Travel Med Infect Dis. 2015;13(6):485-9. https://doi.org/10.1016/j. tmaid.2015.09.008. This 3-year surveillance survey evidences the high prevalence of respiratory symptoms in French pilgrims.

27. Refaey S, Amin MM, Roguski K, Azziz-Baumgartner E, Uyeki TM, Labib M, et al. Cross-sectional survey and surveillance for influenza viruses and MERS-CoV among Egyptian pilgrims returning from Hajj during 2012-2015. Influenza Other Respir Viruses. 2017;11(1):57-60. https://doi.org/10.1111/irv.12429.

28. Benkouiten S, Charrel R, Belhouchat K, Drali T, Nougairede A, Salez N, et al. Respiratory viruses and bacteria among pilgrims during the 2013 Haij. Emerg Infect Dis. 2014;20:1821-7. https:// doi.org/10.3201/eid2011.140600.

29. Memish ZA, Al-Tawfiq JA, Almasri M, Akkad N, Yezli S, Turkestani A, et al. A cohort study of the impact and acquisition of naspharyngeal carriage of Streptococcus pneumoniae during the Hajj. Travel Med Infect Dis. 2016;14(3):242-7. https://doi.org/10. 1016/j.tmaid.2016.05.001.

30. Barasheed O, Rashid H, Alfelali M, Tashani M, Azeem M, Bokhary $\mathrm{H}$, et al. Viral respiratory infections among Hajj pilgrims in 2013. Virol Sin. 2014;29(6):364-71. https://doi.org/10.1007/s12250-0143507-x.

31. Memish ZA, Assiri A, Turkestani A, Yezli S, Al Masri M, Charrel $\mathrm{R}$, et al. Mass gathering and globalization of respiratory pathogens during the 2013 Hajj. Clin Microbiol Infect. 2015;21(6):571.e1-8. https://doi.org/10.1016/j.cmi.2015.02.008. This large cohort study describes the acquisition of respiratory pathogens by pilgrims from 13 different countries.

32. Hashim S, Ayub ZN, Mohamed Z, Hasan H, Harun A, Ismail N, et al. The prevalence and preventive measures of the respiratory illness among Malaysian pilgrims in 2013 Hajj season. J Travel Med. 2016;23:tav019. https://doi.org/10.1093/jtm/tav019.

33. Ma X, Liu F, Liu L, Zhang L, Lu M, Abudukadeer A, et al. No MERS-CoV but positive influenza viruses in returning Hajj pilgrims, China, 2013-2015. BMC Infect Dis. 2017;17(1):715. https://doi.org/10.1186/s12879-017-2791-0.

34. Ganaie F, Nagaraj G, Govindan V, Basha R, Hussain M, Ashraf N, et al. Impact of Hajj on the $S$. pneumoniae carriage among Indian pilgrims during 2016 - a longitudinal molecular surveillance study. Travel Med Infect Dis. 2018;23:64-71. https://doi.org/10.1016/j. tmaid.2018.04.002. This study shows that $\mathbf{6 5 . 9 \%}$ Indian pilgrims were positive for $S$. pneumoniae by qPCR (59\% were symptomatic).

35. Pane M, Imari S, Alwi Q, Nyoman Kandun I, Cook AR, Samaan G. Causes of mortality for Indonesian Hajj Pilgrims: comparison between routine death certificate and verbal autopsy findings. PLoS One. 2013;8(8):e73243. https://doi.org/10.1371/journal.pone. 0073243.

36. Gautret P, Benkouiten S, Al-Tawfiq JA, Memish ZA. Hajjassociated viral respiratory infections: a systematic review. Travel Med Infect Dis. 2016;14(2):92-109. https://doi.org/10.1016/j. tmaid.2015.12.008.

37. Al-Tawfiq JA, Benkouiten S, Memish ZA. A systematic review of emerging respiratory viruses at the Hajj and possible coinfection with Streptococcus pneumoniae. Travel Med Infect Dis. 2018;23: 6-13. https://doi.org/10.1016/j.tmaid.2018.04.007.

38. Annan A, Owusu M, Marfo KS, Larbi R, Sarpong FN, AduSarkodie Y, et al. High prevalence of common respiratory viruses and no evidence of Middle East respiratory syndrome coronavirus in Hajj pilgrims returning to Ghana, 2013. Tropical Med Int Health. 2015;20:807-12. https://doi.org/10.1111/tmi.12482.

39. Gautret P, Benkouiten S, Al-Tawfiq JA, Memish ZA. The spectrum of respiratory pathogens among returning Hajj pilgrims: myths and reality. Int J Infect Dis. 2016;47:83-5. https://doi.org/10.1016/j.ijid. 2016.01.013.

40. Aberle JH, Popow-Kraupp T, Kreidl P, Laferl H, Heinz FX, Aberle SW. Influenza A and B viruses but Not MERS-CoV in Hajj Pilgrims, Austria, 2014. Emerg Infect Dis. 2015;21(4):726-7. https://doi.org/10.3201/eid2104.141745.

41. Lessler J, Rodriguez-Barraquer I, Cummings DA, Garske T, Van Kerkhove M, Mills $\mathrm{H}$, et al. Estimating potential incidence of MERS-CoV associated with Hajj Pilgrims to Saudi Arabia, 2014. PLoS Curr. 2014;24:6. https://doi.org/10.1371/currents.outbreaks. c5c9c9abd636164a9b6fd4dbda974369.

42. Zumla A, Mwaba P, Bates M, A1-Tawfiq JA, Maeurer M, Memish ZA. The Hajj pilgrimage and surveillance for Middle East respiratory syndrome coronavirus in pilgrims from African countries. Tropical Med Int Health. 2014;19(7):838-40. https://doi.org/10. 1111/tmi.12318.

43. Gautret P, Charrel R, Benkouiten S, Belhouchat K, Nougairede A, Drali T, et al. Lack of MERS coronavirus but prevalence of influenza virus in French pilgrims after 2013 Hajj. Emerg Infect Dis. 2014;20(4):728-30. https://doi.org/10.3201/eid2004.131708.

44. Memish ZA, Assiri A, Almasri M, Alhakeem RF, Turkestani A, Al Rabeeah AA, et al. Prevalence of MERS-CoV nasal carriage and compliance with the Saudi health recommendations among pilgrims attending the 2013 Hajj. J Infect Dis. 2014;210(7):1067-72. https://doi.org/10.1093/infdis/jiu150.

45. Gautret P, Charrel R, Belhouchat K, Drali T, Benkouiten S, Nougairede A, et al. Lack of nasal carriage of novel corona virus (HCoV-EMC) in French Hajj pilgrims returning from the Hajj 2012, despite a high rate of respiratory symptoms. Clin Microbiol Infect. 2013;19(7):315-7. https://doi.org/10.1111/1469-0691. 12174.

46. Hashem AM, Azhar EI, Shalhoub S, Abujamel TS, Othman NA, Al Zahrani $\mathrm{AB}$, et al. Genetic characterization and diversity of 
circulating influenza A/H1N1pdm09 viruses isolated in Jeddah, Saudi Arabia between 2014 and 2015. Arch Virol. 2018;163(5): 1219-30. https://doi.org/10.1007/s00705-018-3732-y.

47. Zumla A, Saeed AB, Alotaibi B, Yezli S, Dar O, Bieh K, et al. Tuberculosis and mass gatherings-opportunities for defining burden, transmission risk, and the optimal surveillance, prevention, and control measures at the annual Hajj pilgrimage. Int $\mathrm{J}$ Infect Dis. 2016;47:86-91. https://doi.org/10.1016/j.ijid.2016.02.003.

48. Yezli S, Zumla A, Yassin Y, Al-Shangiti AM, Mohamed G, Turkistani AM, et al. Undiagnosed active pulmonary tuberculosis among pilgrims during the 2015 Hajj mass gathering: a prospective cross-sectional study. Am J Trop Med Hyg. 2017;97(5):1304-9. https://doi.org/10.4269/ajtmh.17-0271. This study shows the high prevalence of undiagnosed active pulmonary tuberculosis among pilgrims.

49. Gautret P, Benkouiten S, Sridhar S, Al-Tawfiq JA, Memish ZA. Diarrhea at the Hajj and Umrah. Travel Med Infect Dis. 2015;13(2):159-66. https://doi.org/10.1016/j.tmaid.2015.02.005. This review paper describes the available data about gastrointestinal diseases among pilgrims.

50. Emamian MH, Mohammad Mohammadi G. An outbreak of gastroenteritis among Iranian pilgrims of Hajj during 2011. Iran Red Crescent Med J. 2013;15(4):317-9. https://doi.org/10.5812/ircmj. 3681.

51. Gautret P, Benkouiten S, Parola P, Brouqui P, Memish Z, Raoult D. Occurrence of Tropheryma whipplei during diarrhea in Hajj pilgrims: a PCR analysis of paired rectal swabs. Travel Med Infect Dis. 2014;12(5):481-4. https://doi.org/10.1016/j.tmaid.2014.04. 003.

52. Sow D, Dogue F, Edouard S, Drali T, Prades S, Battery E, et al. Acquisition of enteric pathogens by pilgrims during the 2016 Hajj pilgrimage: a prospective cohort study. Travel Med Infect Dis. 2018. https://doi.org/10.1016/j.tmaid.2018.05.017.

53. Abd El Ghany M, Alsomali M, Almasri M, Padron Regalado E, Naeem R, Tukestani A, et al. Enteric Infections Circulating during Hajj Seasons, 2011-2013. Emerg Infect Dis. 2017;23(10). https:// doi.org/10.3201/eid2310.161642.

54. Metanat M, Sharifi-Mood B, Sanei-Moghaddam S, Rad NS. Pharyngeal carriage rate of Neisseria meningitidis before and after the Hajj pilgrimage, in Zahedan (southeastern Iran), 2012. Turk J Med Sci. 2015;45(6):1317-20.

55. Leangapichart T, Tissot-Dupont $\mathrm{H}$, Raoult $\mathrm{D}$, Memish ZA, Rolain JM, Gautret P. Risk factors for acquisition of CTX-M genes in pilgrims during Hajj 2013 and 2014. J Antimicrob Chemother. 2017;72(9):2627-35. https://doi.org/10.1093/jac/dkx155.

56. Bawazir SA. Prescribing pattern at community pharmacies in Saudi Arabia. Int Pharm J. 1992;6(5):222-4.

57. Azeem M, Tashani M, Barasheed O. Knowledge, attitude and practice (KAP) survey concerning antimicrobial use among Australian Hajj pilgrims. Infect Disord Drug Targets. 2014;14:125-32.

58. Haseeb A, Faidah HS, Bakhsh AR, Malki WH, Elrggal ME, Saleem F, et al. Antimicrobial resistance among pilgrims: a retrospective study from two hospitals in Makkah, Saudi Arabia. Int J Infect Dis. 2016;47:92-4. https://doi.org/10.1016/j.ijid.2016.06. 006. This study evidence a high prevalence of antimicrobial resistance bacteria in pilgrims hospitalized in Saudi Arabia.

59. Alyamani EJ, Khiyami AM, Booq RY, Majrashi MA, Bahwerth FS, Rechkina E. The occurrence of ESBL-producing Escherichia coli carrying aminoglycoside resistance genes in urinary tract infections in Saudi Arabia. Ann Clin Microbiol Antimicrob. 2017;16:1. https://doi.org/10.1186/s12941-016-0177-6.

60. Leangapichart T, Dia NM, Olaitan AO, Gautret P, Brouqui P, Rolain J-M. Acquisition of extended-spectrum b-lactamases by Escherichia coli and Klebsiella pneumoniae in gut microbiota of pilgrims during the hajj pilgrimage of 2013. Antimicrob Agents Chemother. 2016;60:3222-6. https://doi.org/10.1128/AAC.02396-15.
61. Leangapichart T, Gautret P, Griffiths K, Belhouchat K, Memish Z, Raoult $\mathrm{D}$, et al. Acquisition of a high diversity of bacteria during the Hajj pilgrimage, including Acinetobacter baumannii with blaOXA72 and Escherichia coli with blaNDM-5 carbapenemase genes. Antimicrob Agents Chemother. 2016;60:5942-8. https://doi.org/ 10.1128/AAC.00669-16.

62. Olaitan AO, Dia NM, Gautret P, Benkouiten S, Belhouchat K, Drali $\mathrm{T}$, et al. Acquisition of extended-spectrum cephalosporin- and colistin-resistant Salmonella enterica subsp. enterica serotype Newport by pilgrims during Hajj. Int J Antimicrob Agents. 2015;45(6):600-4. https://doi.org/10.1016/j.ijantimicag.2015.01. 010.

63. Leangapichart T, Gautret P, Brouqui P, Memish ZA, Raoult D, Rolain J-M. Acquisition of mcr-1 plasmid-mediated colistin resistance in Escherichia coli and Klebsiella pneumoniae during Hajj 2013 and 2014. Antimicrob Agents Chemother. 2016;60(11):69989. https://doi.org/10.1128/AAC.01486-16.

64. Al-Tawfiq JA, Memish ZA. Potential risk for drug resistance globalization at the Hajj. Clin Microbiol Infect. 2015;21(2):109-14. https://doi.org/10.1016/j.cmi.2014.11.013.

65. WHO. Health conditions for travelers to Saudi Arabia for the pilgrimage to Mecca (Hajj). 4 August 2017. Available at: http://www. who.int/ith/updates/20170408/en/.

66. Yezli S, Wilder-Smith A, Bin Saeed AA. Carriage of Neisseria meningitidis in the Hajj and Umrah mass gatherings. Int $\mathrm{J}$ Infect Dis. 2016;47:65-70. https://doi.org/10.1016/j.ijid.2015.11.014.

67. Memish ZA, Yezli S, Almasri M, Assiri A, Turkestani A, Findlow $\mathrm{H}$, et al. Meningococcal serogroup A, C, W, and Y serum bactericidal antibody profiles in Hajj pilgrims. Int J Infect Dis. 2014;28: 171-5. https://doi.org/10.1016/j.ijid.2014.09.005.

68. Ceyhan M, Celik M, Demir ET, Gurbuz V, Aycan AE, Unal S. Acquisition of meningococcal serogroup W-135 carriage in Turkish Hajj pilgrims who had received the quadrivalent meningococcal polysaccharide vaccine. Clin Vaccine Immunol 2013:20(1): 66-68. https://doi.org/10.1128/CVI.00314-12.

69. Memish ZA, Al-Tawfiq JA, Almasri M, Azhar EI, Yasir M, AlSaeed MS, et al. Neisseria meningitidis nasopharyngeal carriage during the Hajj: a cohort study evaluating the need for ciprofloxacin prophylaxis. Vaccine. 2017;35(18):2473-8. https://doi.org/10. 1016/j.vaccine.2017.03.027.

70.• Sokhna C, Mboup BM, Sow PG, Camara G, Dieng M, Sylla M, et al. Communicable and non-communicable disease risks at the Grand Magal of Touba: The largest mass gathering in Senegal. Travel Med Infect Dis. 2017;19:56-60. https://doi.org/10.1016/j. tmaid.2017.08.005. The study is the first one conducted among pilgrims at the Grand Magal in Senegal and shows the frequency of infectious diseases among participants

71. Sridhar S, Gautret P, Brouqui P. A comprehensive review of the Kumbh Mela: identifying risks for spread of infectious diseases. Clin Microbiol Infect. 2015;21(2):128-33. https://doi.org/10. 1016/j.cmi.2014.11.021.

72. Cariappa MP, Singh BP, Mahen A, Bansal AS. Kumbh Mela 2013: Healthcare for the millions. Med J Armed Forces India. 2015;71(3): 278-81. https://doi.org/10.1016/j.mjafi.2014.08.001.

73. Al-Lami F, Al-Fatlawi A, Bloland P, Nawwar A, Jetheer A, Hantoosh $\mathrm{H}$, et al. Pattern of morbidity and mortality in Karbala hospitals during Ashura mass gathering at Karbala, Iraq, 2010. East Mediterr Health J. 2013;19(Suppl 2):S13-20.

74. Youbi M, Dghoughi N, Akrim M, Essolbi A, Barkia A, Azami AI, et al. Preparedness and health risks associated with Moulay Abdellah Amghar Moussem, Morocco, 2009-2010. East Mediterr Health J. 2013;19(Suppl 2):S19-20.

75. Hassan S, Imtiaz R, Ikram N, Baig MA, Safdar R, Salman M, et al. Public health surveillance at a mass gathering: Urs of Baba Farid, Pakpattan district, Punjab, Pakistan, December 2010. East Mediterr Health J. 2013;19(Suppl 2):S24-30. 
76. Abdullah S, Sharkas G, Sabri N, Iblan I, Abdallat M, Jriesat S, et al. Mass gathering in Aqaba, Jordan, during Eid Al Adha, 2010. East Mediterr Health J. 2013;19(Suppl 2):S29-30.

77. Centers for Disease Control and Prevention (CDC). Outbreak of salmonellosis associated with consumption of pulled pork at a church festival-Hamilton County, Ohio, 2010. MMWR Morb Mortal Wkly Rep. 2014;62:1045-7.

78. Botelho-Nevers E, Gautret P. Outbreaks associated to large open air festivals, including music festivals, 1980 to 2012. Euro Surveill. 2013;18:20426.

79. Tabunga T, Utiera M, Tekoaua R, Tibwe T, Tira T, Toatu T, et al. Response to a large rotavirus outbreak on South Tarawa, Kiribati, 2013. Western Pac Surveill Response J. 2014;5(2):9-14. https://doi. org/10.5365/wpsar.2013.4.4.006.

80. Grgič-Vitek M, Frelih T, Ucakar V, Fafangel M, Jordan Markocic $\mathrm{O}$, Prosenc K, et al. An outbreak of measles associated with an international dog show in Slovenia, November 2014. Euro Surveill. 2015;20(3).

81. McCarthy M. Measles outbreak linked to Disney theme parks reaches five states and Mexico. BMJ. 2015;350:h436. https://doi. org/10.1136/bmj.h436.

82. Kanai M, Kamiya H, Smith-Palmer A, Takahashi H, Hachisu Y, Fukusumi M, et al. Meningococcal disease outbreak related to the World Scout Jamboree in Japan, 2015. Western Pac Surveill Response J. 2017;8(2):25-30. https://doi.org/10.5365/WPSAR. 2016.7.3.007. This study describes the high incidence of meningococcal disease in a large-scale open-air festival, far exceeding the annual incidence rate in the host country.

83. le Polain de Waroux O, Saliba V, Cottrell S, Young N, Perry M, Bukasa A, et al. Summer music and arts festivals as hot spots for measles transmission: experience from England and Wales, June to October 2016. Euro Surveill. 2016;21(44). https://doi.org/10.2807/ 1560-7917.ES.2016.21.44.30390.

84.• Gautret P, Steffen R. Communicable diseases as health risks at mass gatherings other than Hajj: what is the evidence? Int J Infect Dis. 2016;47:46-52. https://doi.org/10.1016/j.ijid.2016.03.007. This review paper describes the available data about infectious diseases at mass gathering other than Hajj.

85. Gardy JL, Naus M, Amlani A, Chung W, Kim H, Tan M, et al. Whole-genome sequencing of measles virus genotypes H1 and D8 during outbreaks of infection following the 2010 Olympic Winter Games reveals viral transmission routes. J Infect Dis. 2015(212): 1574-8. https://doi.org/10.1093/infdis/jiv271.

86. Santibanez S, Prosenc K, Lohr D, Pfaff G, Jordan Markocic O, Mankertz A. Measles virus spread initiated at international mass gatherings in Europe, 2011. Euro Surveill. 2014;19(35).

87. McCloskey B, Endericks T, Catchpole M, Zambon M, McLauchlin J, Shetty N, et al. London 2012 Olympic and Paralympic Games: public health surveillance and epidemiology. Lancet. 2014;383(9934):2083-9. https://doi.org/10.1016/S0140-6736(13) 62342-9.
88. Sile B, Mohammed H, Crook P, Hughes G, Mercer C, Cassel J, et al. Epidemiology of sexually transmitted infections in visitors for the London 2012 Olympic games: a review of attendees at sexual health services. Sex Transm Dis. 2015;42(12):710-6. https://doi. org/10.1097/OLQ.0000000000000370.

89. Smallwood CAH, Arbuthnott KG, Banczak-Mysiak B, Borodina M, Coutinho AP, Payne-Hallström L, et al. Euro 2012 European football championship finals: planning for a health legacy. Lancet. 2014;383(9934):2090-7. https://doi.org/10.1016/S0140-6736(13) 62384-3.

90. van Beijsterveldt AM, Thijs KM, Backx FJ, Steffen K, Brozičević $\mathrm{V}$, Stubbe JH. Sports injuries and illnesses during the European Youth Olympic Festival 2013. Br J Sports Med. 49(7):448-52. https://doi.org/10.1136/bjsports-2014-094035.

91. Soligard T, Steffen K, Palmer-Green D, Aubry M, Grant ME, Meeuwisse W, et al. Sports injuries and illnesses in the Sochi 2014 Olympic Winter Games. Br J Sports Med. 2015;49(7):4417. https://doi.org/10.1136/bjsports-2014-094538.

92. Aguiar M, Coelho GE, Rocha F, Mateus L, Pessanha JE, Stollenwerk N. Dengue transmission during the 2014 FIFA World Cup in Brazil. Lancet Infect Dis. 2015;15(7):765-6. https://doi.org/ 10.1016/S1473-3099(15)00073-0.

93. Pesola AK, Parn T, Huusko S, Perevosc ikovs J, Ollgren J, Salmenlinna S, et al. Multinational outbreak of Salmonella enteritidis infection during an international youth ice hockey competition in Riga, Latvia, preliminary report, March and April 2015. Euro Surveill. 2015;20(20).

94. Soligard T, Steffen K, Palmer D, Alonso JM, Bahr R, Lopes AD, et al. Sports injury and illness incidence in the Rio de Janeiro 2016 Olympic Summer Games: a prospective study of 11274 athletes from 207 countries. Br J Sports Med. 2017;51(17):1265-71. https://doi.org/10.1136/bjsports-2017-097956.

95. Hamilton B, Exeter D, Beable S, Coleman L, Milne C. Zika virus and the Rio Olympic Games. Clin J Sport Med. 2017; https://doi. org/10.1097/JSM.0000000000000551.

96. Tavernise. No Zika cases reported during Rio Olympics, W.H.O. Says. New York Times; 2016. Available at: https://www.nytimes. com/2016/09/03/health/zika-rio-olympics.html. Accessed September 5, 2016.

97. Sheridan. Multiple Outbreaks Threaten the 2018 Winter Olympics. The disease Daily 14 February 2018. Available at: http:/www. healthmap.org/site/diseasedaily/article/multiple-outbreaksthreaten-2018-winter-olympics-21418

98. Benkouiten S, Brouqui P, Gautret P. Non-pharmaceutical interventions for the prevention of RTIs during Hajj pilgrimage. Travel Med Infect Dis. 2014;12(5):429-42. https://doi.org/10.1016/j.tmaid. 2014.06.005.

99. Al-Tawfiq JA, Gautret P, Memish ZA. Expected immunizations and health protection for Haij and Umrah 2018 -an overview. Travel Med Infect Dis. 2017;2017(19):2-7. https://doi.org/10.1016/j. tmaid.2017.10.005. 